\title{
IDE DIVERSI DALAM TINDAK PIDANA RINGAN YANG DILAKUKAN ORANG DEWASA BERBASIS KEADILAN
}

\author{
Riya Novita \\ Hakim Pengadilan Negeri \\ Riyanovita0776@gmail.com
}

\begin{abstract}
Indonesia's legal system which applies to offenders focuses on punishment as the penalty. Kajahatan perpetrators will be punished so that security and order within the community can be restored sehigga impressed penalty is revenge on the perpetrators of crime victims. But the punishment will never improve the state of society, because it does not deter criminals from committing a similar crime or even a more heinous, also ignoring the losses suffered by victims. The researchers' goal here, to put the idea of diversion is the transfer of criminal cases outside the criminal justice process. This type of research is the description of the analysis is to do research that will be devoted to seek or find the data needed to answer the problem. The results of this study are known to retributive punishment does not guarantee reduced crime. It is based on the data presented Writer, convictions resulted in the over-capacity prison. By applying a misdemeanor diversion in the task of law enforcement to be reduced, budget handling criminal offenses can be diverted to handling criminal offense heavier and their diversion agreement then the victim is much more attention.
\end{abstract}

Keywords: misdemeanor, sentencing, restorative, versioned

\begin{abstract}
Abstrak
Di Indonesia sistem hukum yang berlaku bagi pelaku kejahatan bertitik berat pada hukuman sebagai balasan yang setimpal. Pelaku kajahatan harus mendapatkan hukuman agar keamanan dan ketertiban dalam masyarakat dapat dipulihkan sehigga terkesan hukuman adalah balas dendam korban pada pelaku kejahatan. Akan tetapi hukuman tidak akan pernah memperbaiki keadaan masyarakat, karena tidak membuat jera para penjahat agar tidak melakukan kejahatan serupa atau bahkan yang lebih keji, juga mengabaikan kerugian yang dialami korban. Tujuan peneliti disini, untuk menerapkan ide diversi yaitu pengalihan perkara pidana ke luar proses peradilan pidana. Jenis penelitian adalah deskripsi analisis yaitu melakukan penelitian yang akan ditujukan untuk mencari atau menemukan data yang dibutuhkan untuk menjawab permasalahan. Hasil dari penelitian ini adalah diketahui pemidanaan retributif tidak menjamin berkurangnya tindak pidana. Hal ini berdasarkan data yang disajikan Penulis, pemidanaan mengakibatkan adanya over capacity Lapas. Dengan menerapkan diversi dalam tindak pidana ringan maka tugas penegak hukum menjadi berkurang, anggaran penanganan tindak pidana dapat dialihkan untuk penanganan tindak pidana yang lebih berat dan adanya kesepakatan diversi maka korban jauh lebih diperhatikan.
\end{abstract}

Kata kunci: tindak pidana ringan, pemidanaan, restoratif, diversi. 


\section{A. Pendahuluan}

Menurut pengertiannya masyarakat adalah sekelompok orang yang membentuk suatu sistem, dimana sebagian besar interaksi adalah antar individu-individu yang berada dalam kelompok itu. Adanya interaksi jangka panjang dalam suatu kelompok dapat menimbulkan adanya konflik antar individu, yang jika dibiarkan akan merusak tatanan hidup masyarakat tersebut. Untuk itulah diperlukan hukum dimana tujuan hukum secara umum adalah untuk menciptakan, ketertiban, kedamaian, kebahagian dalam kehidupan masyarakat.

Jika terjadi kejahatan maka faktor penting keberhasilan penegakan hukum adalah keadilan dapat dirasakan masyarakat sehingga kehidupan bersama dapat bertahan. Di Indonesia sistem hukum yang berlaku bagi pelaku kejahatan bertitik berat pada hukuman sebagai balasan yang setimpal. Pelaku kajahatan harus mendapatkan hukuman agar keamanan dan ketertiban dalam masyarakat dapat dipulihkan sehigga terkesan hukuman adalah balas dendam korban pada pelaku kejahatan.

Praktek peradilan yang demikian adalah penerapan dari keadilan retributif yaitu keadilan yang menitikberatkan pada pemberian hukuman bagi pelaku kejahatan. Praktek peradilan yang demikian haruslah ditopang sistem hukum yang kuat karena jika tidak yang terjadi adalah kekecewaan masyarakat dan sama sekali tidak memberi rasa aman.

Sudah lama sistem keadilan retributif atau punitif diragukan efektifitasnya. Hukuman seberat apapun kepada pelaku kejahatan tidak akan pernah memberi keamanan dan kesejahteraan pada masyarakat. Hukuman tidak akan pernah memperbaiki keadaan masyarakat, karena tidak membuat jera para penjahat agar tidak melakukan kejahatan serupa atau bahkan yang lebih keji. Kejahatan mesti harus didefinisikan ulang, dan dianalisis akar dan sebab musababnya. Kejahatan manusia tidak akan hilang oleh karena hu- kuman, sebab adanya hukuman didasari oleh konsep yang sama sekali berbeda. ${ }^{1}$

Tolak ukur keberhasilan penegakan hukum bukan terletak pada banyaknya pelaku kejahatan menjadi penghuni penjara akan tetapi terciptanya pemulihan keadaan korban atau masyarakat sehingga terciptalah keamanan, ketertiban, dan kedamaian sebagaimana tujuan hukum. Pemidanaan yang berorientasi hukuman penjara dirasa tidak lagi menciptakan efek jera bagi para pelaku kejahatan bahkan beberapa kasus, hukuman penjara dapat menjadikan pelaku kejahatan menjadi lebih terasah kemampuannya untuk melakukan tindak pidana, dan juga yang harus menjadi pemikiran adalah adanya over capacity rutan atau lapas yang tentu saja menambah beban anggaran pemerintah untuk "membiayai" narapidana yang ada di rutan atau lapas.

Selain daripada itu keadilan retributif cenderung mengabaikan kepentingan korban, pelaku kejahatan hanya cukup mempertanggungjawabkan perbuatannya dengan menjalani hukuman penjara sedangkan korban yang secara nyata mengalami kerugian tidak mendapat kompesasi atau ganti rugi yang sesuai dengan kerugian ataupun penderitaan akibat kejahatan yang terjadi.

Contoh kasus yang mengusik rasa keadilan adalah kasus yang menimpa Nenek Minah dimana kisah yang terjadi pada tahun 2009 berawal ketika Nenek Minah mengambil tiga biji kakao yang terjatuh di tanah untuk dibawa pulang dan dijadikan benih akan tetapi sebelum dibawa pulang, Mandor perkebunan lewat melihat biji kakao yang diambil Nenek Minah dan Nenek Minah dibawa ke Kantor Polisi untuk di proses sampai ke persidangan dan Nenek Minah dinyatakan terbukti melakukan pencurian dan dipidana 1 bulan 15 hari dengan masa percobaan 3 bulan.

1 Keadilan Restoratif, Yoachim Agus Tridiatmo, Cahya Atma Pusaka Kelompok Penerbit Universitas Atmajaya Yogyakarta, hIm 6, 2015. 
Kasus Nenek Minah seharusnya dapat diselesaikan tanpa melalui proses peradilan, akan tetapi karena sistem hukum di Indonesia yang mengharuskan pelaku tindak pidana harus dijatuhi hukuman dan yang membedakan adalah apakah tindak pidana tersebut masuk dalam acara pemeriksaan biasa ataupun singkat tetapi tujuan akhirnya adalah pemidanaan, adanya perdamaian antara pelaku tindak pidana dengan korban hanya dijadikan alasan yang meringankan.

Seharusnya ada proses peralihan agar pelaku kejahatan tindak pidana ringan tidak perlu menjalani proses persidangan. Di Indonesia proses peralihan yang demikian telah diimplementasikan dalam UU No 11 tahun 2012 tentang sistem Peradilan Pidana Anak yaitu adanya suatu proses yang disebutkan diversi. Didalam Pasal 1 huruf 7 disebutkan diversi adalah pengalihan penyelesaian perkara anak dari proses peradilan pidana ke proses di luar peradilan pidana. Proses diversi melibatkan pelaku, korban, keluarga, dan pihakpihak lain yang terkait dengan menekankan pemulihan keadaan. Kesepakatan yang tercapai dari proses diversi akan dituangkan dalam suatu penetapan Ketua Pengadilan Negeri yang bernilai sama dengan putusan yang telah berkekuatan hukum yang tetap sehingga mempunyai daya paksa untuk pelaksanaannya.

Undang-Undang No 11 Tahun 2012 tentang Sistem Peradilan Anak Pasal 7 menyebutkan:

(1) Pada tingkat penyidikan, penuntutan, dan pemeriksaan perkara Anak di pengadilan negeri wajib diupayakan Diversi.

(2) Diversi sebagaimana dimaksud pada ayat (1) dilaksanakan dalam hal tindak pidana yang dilakukan:

a. diancam dengan pidana penjara di bawah 7 (tujuh) tahun; dan

b. bukan merupakan pengulangan tindak pidana.

Dalam Pasal 7 ayat (2) UndangUndang No 11 Tahun 2012 tentang Sistem
Peradilan Anak secara jelas diatur mengenai syarat dilakukannya diversi salah satunya tindak pidana yang dilakukan adalah diancam dengan pidana penjara dibawah 7 (tujuh) tahun. Jika dibandingkan tindak pidana ringan adalah tindak pidana dengan ancaman paling lama 3 (tiga) bulan, maka sangat di mungkinkan dapat diselesaikan tanpa melalui proses peradilan pidana.

\section{B. Masalah Hukum}

1. Apakah diperlukan diversi dalam tindak pidana ringan yang dilakukan orang dewasa?

2. Apa pengaruh diversi dalam tindak pidana ringan yang dilakukan orang dewasa?

\section{Metode Penelitian}

Metode yang digunakan adalah deskriptif analisis karena penelitian yang akan dilakukan ditujukan untuk mencari atau menemukan data yang dibutuhkan untuk menjawab permasalahan yang kemudian akan dijabarkan atau dipaparkan untuk memberikan gambaran yang komprehensif tentang jawaban atas permasalahan yang diangkat dalam penelitian.

\section{Hasil Penelitian}

Hukum untuk manusia, bukan manusia untuk hukum. Ungkapan ini menjadi dasar adanya paradigma baru mengenai keadilan restoratif. Restorative justice berawal dari negara-negara yang mempergunakan bahasa Inggris, seperti Kanada, Australia, New Zealand, dan Inggris. ${ }^{2} \mathrm{Ke}-$ adilan restoratif yaitu keadilan yang mendorong perubahan pemulihan keadaan karena terjadinya kejahatan bukan dengan menitikberatkan hukuman pada pelaku kejahatan tetapi dengan memulihkan hubungan antara pelaku dan korban sehingga terciptalah kehidupan bersama.

Keadilan restoratif adalah bentuk keadilan yang berpusat pada kebutuhan korban, pelau kejahatan dan masyarakat. Berbeda dengan keadilan retributif yang menekankan hukuman bagi pelaku keja-

2 Varia Peradilan Tahun ke XX No.247 Juni 2006, hlm. 3 
hatan, keadilan restoratif mementingkan pemulihan korban, pelaku kejahatan, dan masyarakat. Hal ini dikarenakan bahwa di dalam setiap tindak kejahatan, korbanlah yang pertama-tama menderita sebagai akibat tindak kejahatan. Selanjutnya pelaku kejahatan sebagai pihak yang bertanggung jawab atas tindakan yang dilakukannya dituntut untuk bertanggungjawab atas tindakannya. Dengan bertanggungjawab itulah martabatnya sebagai pribadi dipulihkan. Masyarakat pun harus dipulihkan, karena tindak kejahatan juga merusak harmoni kehidupan di dalam masyarakat. ${ }^{3}$

Penanganan perkara pidana dengan menggunakan pendekatan keadilan restorative menawarkan pandangan dan pendekatan yang berbeda dalam memahami dan menangani suatu tindak pidana, seperti tergambar dari definisi yang dikemukakan oleh Dignan sebagai berikut:

Restorative justice is a new framework for responding to wrong doing and conflict that is rapidly gaining acceptance and support by educational, legal, social work, and counseling professionals and community groups. Restorative justice is a valued-based approach to responding to wrongdoing and conflict, with a balanced focus on the person harmed, the person causing the harm, and the affected community. ${ }^{4}$

Definisi tersebut di atas mensyaratkan adanya suatu kondisi tertentu yang menempatkan keadilan restorative sebagai nilai dasar yang dipakai dalam merespon suatu perkara pidana. Dalam hal ini disyaratkan adanya keseimbangan fokus perhatian antara kepentingan pelaku dan korban serta memperhitungkan pula dampak penyelesaian perkara pidana tersebut dalam masyarakat. Karena kelemahan dari peradilan pidana yang ada saat ini adalah pada posisi korban

3 Keadilan Restoratif, Yoachim Agus Tridiatmo, Cahya Atma Pusaka Kelompok Penerbit Universitas Atma jaya Yogyakarta, hlm 27, 2015

4 www.djpp.depkumham.go.id/../927-restorative-justice, diakses tanggal 10 November 2016 jam 14.00 WIB. dan masyarakat yang belum mendapatkan posisinya sehingga kepentingan keduanya menjadi terabaikan. Sementara dalam model penyelesaian perkara pidana dengan menggunakan pendekatan keadilan restorative peran aktif kedua pihak ini menjadi penting disamping peran pelaku. ${ }^{5}$

Restorative Justice sebagai salah usaha untuk mencari penyelesaian konflik secara damai di luar pengadilan masih sulit diterapkan. Di Indonesia banyak hukum adat yang bisa menjadi restorative justice, namun keberadaannya tidak diakui negara atau tidak dikodifikasikan dalam hukum nasional. Hukum adat bisa menyelesaikan konflik yang muncul di masyarakat dan memberikan kepuasan pada pihak yang berkonflik. Munculnya ide restorative justice sebagai kritik atas penerapan sistem peradilan pidana dengan pemenjaraan yang dianggap tidak efektif menyelesaikan konflik sosial. Penyebabnya, pihak yang terlibat dalam konflik tersebut tidak dilibatkan.

Di sisi lain jika dihubungkan dalam hal pertanggunganjawab atas perbuatan yang dilakukan merugikan orang lain (pemidanaan) khususnya di Indonesia, yaitu dengan keberadaan KUHP (Kitab Undang-undang Hukum Pidana) yaitu UU No. 1 Tahun 1945), bahwa suatu perbuatan yang merugikan orang lain dapat dijerat dengan pasal-pasal yang ada dalam KUHP. Kemudian setelah masuk dalam proses peradilan pidana, maka orang yang melakukan tindak kejahatan sebagaimana yang diatur dalah KUHP, maka akan diterapkan hukum formil yaitu Undang-Undang No. 8 Tahun 1981 tentang KUHAP.

Dengan mendasarkan pada KUHP dan KUHAP dapat dipastikan tujuan akhir dari proses peradilan pidana adalah suatu pemidanaan, walaupun misalnya apabila telah terjadi perdamaian antara pelaku dan korban, dan sang korban telah memaafkan sang pelaku, maka hal tersebut tidak akan bisa mempengaruhi

5 www.djpp.depkumham.go.id/.../927-restorative-justice diakses tanggal 10 November 2016 jam 14.00 WIB. 
kewenangan penegak hukum untuk terus meneruskan perkara tersebut ke ranah pidana yang nantinya berujung pada pemidanaan sang pelaku pidana. Proses formal pidana yang makan waktu lama serta tidak memberikan kepastian bagi pelaku maupun korban tentu tidak serta merta memenuhi maupun memulihkan hubungan antara korban dan pelaku.

Berdasarkan KUHP dan KUHAP, seorang pelaku tindak pidana kejahatan akan menjalani proses peradilan pidana yang akan berakhir di pengadilan dan untuk dapat membedakan acara pemeriksaan perkara di sidang pengadilan dapat di lihat dari jenis tindak pidana yang akan di ajukan ke muka sidang pengadilan.

1. Perkara yang akan diajukan ke muka sidang pengadilan pembuktiannya sulit atau mudah.

2. Berat ringannya ancaman pidana atas perkara yang akan diajukan ke muka sidang pengadilan.

3. Jenis perkara yang akan diajukan ke muka sidang pengadilan.

Atas perbedaan kategori dari tiap-tiap perkara yang akan di ajukan ke muka sidang pengadilan, menurut KUHAP ada tiga jenis acara pemeriksaan perkara pidana di sidang pengadilan:

1. Acara pemeriksaan biasa di atur dalam KUHAP bagian ketiga Bab XVI

2. Acara pemeriksaan singkat di atur dalam KUHAP bagian kelima bab $\mathrm{XVI}$

3. Acara pemeriksaan cepat diatur dalam KUHAP bagian keenam bab $\mathrm{XVI}$, yang terdiri dari:

a). Acara pemeriksaan perkara tindak pidana ringan

b). Acara pemeriksaan perkara pelanggaran lalu lintas jalan. ${ }^{6}$

Adapun mengenai tindak pidana yang termasuk dalam pemeriksaan acara ringan, undang-undang tidak menjelaskan. Akan tetapi undang-undang menentukan patokan dari segi "ancaman pidananya".

6 www.menujuhukum.blogspot.com, diakses tanggal 05 Desember 2016 jam 10.00 WIB
Untuk menentukan apakah suatu tindak pidana diperiksa dengan acara ringan, bertitik tolak dari ancaman pidana yang didakwakan. Secara generalisasi, ancaan pidana yang menjadi ukuran dalam acara pemeriksaan tindak pidana ringan, diatur dalam Pasal 205 ayat (1) KUHAP yakni:

i. Tindak pidana yang ancaman pidananya "paling lama 3 bulan" penjara atau kurungan,

ii. Atau denda sebanyak-banyaknya Rp. 7.500,- dan

iii. "Penghinaan ringan" yang dirumuskan dalam Pasal 315 KUHP.7 $^{7}$

Sampai saat ini belum ada batasan tindak pidana apa yang boleh diterapkan dan yang tidak boleh diterapkan restorasi justice. Karena titik tolak batasan penerapan restorative justice bukan dari jenis tindak pidana, tapi dari persetujuan korban dan persetujuan pelaku dan jika melihat dari kriteria tindak pidana ringan di atas, maka yang bisa sangat memungkinkan untuk diterapkannya restorative justice adalah tindak pidana ringan sebagai contoh kasus Nenek Minah yang mencuri 3 buah kakao, kasus Nenek Asyani yang dituduh mencuri tujuh batang kayu milik Perhutani, dengan melihat kecilnya kerugian maka perkara dapat dialihkan melalui suatu proses yang tujuannya adalah memulihkan keadaan seperti semula.

Proses peralihan proses pidana di Indonesia dikenal dengan istilah diversi. Di Indonesia diversi mulai diatur dan diimplementasikan dalam UU No 11 tahun 2012 tentang sistem Peradilan Pidana Anak. Didalam Pasal 1 huruf 7 disebutkan diversi adalah pengalihan penyelesaian perkara anak dari proses peradilan pidana ke proses di luar peradilan pidana.

Jika dikaitkan dengan kriteria tindak pidana ringan maka penanganan kasus yang memenuhi syarat-syarat tindak pidana ringan dapat dikenakan proses di-

7 Pembahasan Permasalahan Dan Penerapan KUHAP Pemeriksan Sidang Pengadilan, Banding, Kasasi, dan Peninjauan Kembali, M. Yahya Harahap, S.H, Sinar Grafika, hIm 422-423, 2008 
versi. Dimana penyelesaiannya memberikan keleluasaan kepada pelaku, korban, dan aparat penegak huku yang berwenang merumuskan sanksi yang tepat bagi pelaku dan ganti rugi bagi korban atau masyarakat. Hal ini dikarenakan prinsip utama dari diversi dan restorative justice adalah menghindarkan pelaku tindak pidana dari system peradilan pidana formal dan memberikan kesempatan pelaku menjalankan sanksi alternatif tanpa pidana penjara.

Proses penyelesaian perkara pidana berdasarkan hukum yang berlaku di Indonesia saat ini dilakukan dalam suatu sistem peradilan pidana (Criminal justice system). Sistem Peradilan Pidana atau Criminal Justice System kini telah menjadi suatu istilah yang menunjukan mekanisme kerja dalam penanggulangan kejahatan dengan mempergunakan dasar pendekatan sistem.

Sistem peradilan pidana adalah sistem pengendalian kejahatan yang terdiri dari lembaga-lembaga kepolisian, kejaksaan, pengadilan, dan lembaga pemasyarakatan. Berdasarkan apa yang dikemukakan tersebut terlihat bahwa komponen atau sub sistem dalam sistem peradilan pidana adalah kepolisian, kejaksaan, pengadilan dan lembaga pemasyaraka$\tan ^{8}$

Penegakan hukum melalui sistem peradilan pidana memerlukan pembiayaan yang sudah tercantum dan ditentukan dalam anggaran negara, dimulai dari proses penyelidikan, penyidikan hingga pemberkasan, bahkan setelah penjatuhan pidana yang yang berujung pada pemidanaan penjara, negara diharuskan untuk "menghidupi" terpidana di penjara, semua itu membutuhkan anggaran yang tidak sedikit.

Indonesia yang masih menggunakan paradigma pemidanaan penjara, mempunyai permasalahan yang harus segera diselesaikan adalah adanya "over capacity" terpidana di Lembaga Pema-

8 Romli Atmasasmita, Sistem Peradilan Pidana Kontemporer, (Jakarta: Kencana Prenada Media Grup, 2010), hlm. 2 sayarakatan dan Rumah Tahanan Negara oleh karena itu dibutuhkan anggaran yang sangat besar untuk membangun infrastruktur baru berkaitan dengan pembinaan terpidana di Lembaga Pemasyarakatan ataupun Rumah Tahanan Negara.

Restorative Justice dalam bentuk diversi adalah bentuk yang paling disarankan dalam menyelesaikan kasus Nenek Minah dan Nenek Asyani dan kasus-kasus lain yang termasuk dalam tindak pidana ringan, sehingga kasus-kasus tindak pidana ringan tidak perlu menjalani proses peradilan pidana. Hal ini dikarenakan proses diversi melibatkan berbagai pihak untuk menyelesaikan suatu permasalahan yang terkait dengan tindak pidana yang terjadi. Dalam proses diversi melibatkan pelaku, korban, keluarga, dan pihak-pihak lain yang terkait dengan menekankan pemulihan keadaan. Kesepakatan yang tercapai dari proses diversi akan dituangkan dalam suatu penetapan Ketua Pengadilan Negeri yang bernilai sama dengan putusan yang telah berkekuatan hukum yang tetap sehingga mempunyai daya paksa untuk pelaksanaannya.

\section{E. Penutup}

\section{Kesimpulan}

Dengan menerapkan proses diversi pada tindak pidana ringan yang dilakukan orang dewasa maka hasil yang diharapkan ialah:

a. Pelaku pidana dapat menyadari kesalahannya sehingga tidak mengulangi perbuatannya.

b. Dengan adanya perdamaian maka tidak menimbulkan rasa dendam karna pelaku telah dimaafkan oleh korban.

c. Mengurangi beban kerja Polisi, Jaksa, Rutan, Pengadilan dan Lapas sehingga menghemat keuangan negara.

\section{Saran}

Pemerintah dan DPR diharapkan segera memasukkan proses diversi ke dalam Rancangan Kitab Undang-Undang Hukum Pidana dan juga pelaksanaan proses diversi ke dalam Rancangan Kitab Undang-Undang Hukum Acara Pidana. 


\section{Daftar Pustaka}

\section{Buku}

M. Yahya Harahap, S.H, Pembahasan Permasalahan Dan Penerapan KUHAP Pemeriksan Sidang Pengadilan, Banding, Kasasi, dan Peninjauan Kembali, Sinar Grafika, 2008

Romli Atmasasmita, Sistem Peradilan Pidana Kontemporer, (Jakarta: Kencana Prenada Media Grup, 2010)

Varia Peradilan Tahun ke XX No.247 Juni 2006

Yoachim Agus Tridiatmo, Keadilan Restoratif, Cahya Atma Pusaka Kelompok Penerbit Universitas Atmajaya Yogyakarta

\section{Internet}

www.djpp.depkumham.go.id/.../927-restorative-justice, diakses tanggal 10 November 2016 jam 14.00 WIB.

www.djpp.depkumham.go.id/.../927-restorative-justice, diakses tanggal 10 November 2016 jam 14.00 WIB.

www.menujuhukum.blogspot.com, diakses tanggal 05 Desember 2016 jam 10.00 WIB 